\title{
Mortality and cancer morbidity of production workers in the UK flexible polyurethane foam industry: updated findings, 1958-98
}

\section{T Sorahan, L Nichols}

See end of article for authors' affiliations

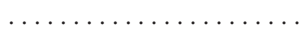

Correspondence to: Prof. T Sorahan, Institute of Occupational Health, University of Birmingham, Edgbaston, Birmingham B15 2TT, UK:

T.M.Sorahan@bham.ac.uk

Accepted 10 April 2002

\begin{abstract}
Aims: To describe cause specific mortality and site specific cancer morbidity among workers employed in factories that produce polyurethane foams, and to determine if any part of the experience may be caused by occupation, in particular to investigate any association between respiratory disease (malignant and non-malignant) and exposure to diisocyanates.

Methods: The mortality (1958-98) and cancer morbidity (1971-94) experienced by a cohort of 8288 male and female employees from 11 factories in England and Wales engaged in the manufacture of flexible polyurethane foams were investigated. All employees were employed for at least six months with some period of employment in the period 1958-79. Two analytical approaches were used, indirect standardisation and Poisson regression.

Results: Compared with the general population of England and Wales, mortality from lung cancer in female employees was significantly increased (observed (Obs) 35, expected (Exp) 19.4, standardised mortality ratio (SMR) 181). A similar excess was not found for male employees (Obs 134, Exp 125.0, SMR 107). There were no significantly increased cause specific SMRs among the subcohort $(n=1782)$ with some period of isocyanate exposed employment. No significant positive trends were found between risks of lung cancer or risks of non-malignant diseases of the respiratory system and durations of "lower" or "higher" exposures to diisocyanates.

Conclusions: The study has been unable to link isocyanate exposed employment either with risks of lung cancer or with risks of non-malignant diseases of the respiratory system. The increased SMR for female lung cancer is most likely caused by factors unrelated to the industry under study.
\end{abstract}

$\mathrm{T}$ he first report into mortality and cancer morbidity of production workers in the UK flexible polyurethane foam industry was published in 1993. ${ }^{1}$ The report provided observed and expected numbers of deaths for the period 1958-88, and corresponding figures for cancer registrations for the period 1971-86. Compared with the general population of England and Wales, statistically significantly increased standardised mortality ratios (SMRs) were found among female employees for cancer of the pancreas $(\mathrm{Obs}=6, \mathrm{SMR}=$ $271)$ and cancer of the lung $(\mathrm{Obs}=16, \mathrm{SMR}=176)$. Similar excesses were not found among male employees, and the SMRs for cancers of the lung and pancreas among the total study population were $100(\mathrm{Obs}=81)$ and $136(\mathrm{Obs}=14)$ respectively. Poisson regression techniques did not indicate that ever having been employed in jobs attracting exposure to isocyanates (mainly toluene diisocyanate (TDI) with some exposure to methylene diphenyldiisocyanate (MDI)) was a risk factor for these cancers. The report concluded that the excess SMRs in female employees were probably caused by a combination of smoking, chance, and factors unrelated to the industry under study.

Two reports also appeared in 1993 providing information on the cancer experience of workers in the Swedish polyurethane foam manufacturing industry. ${ }^{2}{ }^{3}$ In the first report, a cohort comprising 4154 male and female production workers from nine Swedish factories was described. ${ }^{2}$ All study subjects were employed for at least one year in the period 1958-86 and the report provided observed and expected numbers of deaths and cancer registrations for the period 1959-87. Compared with the general population of Sweden, statistically significantly increased SMRs were not found for any site of cancer. Overall incidence of cancer was below expectation, although increased standardised registration ratios (SRRs) were shown for cancer of the rectum and for non-Hodgkin's lymphoma in study subjects with exposure to TDI when the first 10 years of follow up were ignored. These SRRs were based on small numbers and did not approach levels of statistical significance (cancer of the rectum: Obs $=3, \mathrm{SRR}=319$; non-Hodgkin's lymphoma: Obs $=2$, SRR $=303$ ). For the second report from the Swedish industry, a nested case-control study was carried out on an enlarged cohort. ${ }^{3}$ There was no longer a minimum duration of employment; the available cohort now comprised 7023 study subjects. For each case of cancer, three controls were selected from the cohort matching on plant, sex, and year of birth. More detailed assessments of TDI exposures were carried out for these cases and controls. The tentative associations between TDI exposure and risks of cancer of the rectum and non-Hodgkin's lymphoma described in the first report ${ }^{2}$ were not supported in this more sophisticated analysis. However, non-significant associations were shown for prostate cancer and colon cancer.

Findings from a mortality study of workers exposed to TDI in the US polyurethane industry were published in $1996 .{ }^{4}$ The cohort comprised 4611 male and female employees from four polyurethane plants. Findings were unexceptional, although the study had a relatively short period of follow up.

The International Agency for Research on Cancer (IARC) has evaluated TDI as a group 2B carcinogen (possibly

Abbreviations: Exp, expected; IARC, International Agency for Research on Cancer; MDI, methylene diphenyldiisocyanate; Obs, observed; ONS, Office for National Statistics; SMR, standardised mortality ratio; SRR, standardised registration ratio; TDI, tolvene diisocyanate; TWA, time weighted average exposure 
Table 1 Definition of factory cohorts and summary of work history data

\begin{tabular}{|c|c|c|c|c|c|c|c|c|}
\hline \multirow[b]{2}{*}{ Factory } & \multicolumn{2}{|c|}{ Census cohort } & \multicolumn{2}{|l|}{ Entry cohort } & \multirow{2}{*}{$\begin{array}{l}\text { Type of } \\
\text { production } \ddagger\end{array}$} & \multirow{2}{*}{$\begin{array}{l}\text { Type of } \\
\text { diisocyanate }\end{array}$} & \multirow{2}{*}{$\begin{array}{l}\text { Work history } \\
\text { data§̧ }\end{array}$} & \multirow{2}{*}{$\begin{array}{l}\text { Size of job } \\
\text { dictionary }\end{array}$} \\
\hline & Census date & $\mathrm{n}^{*}$ & Year of hire & $\mathrm{n} \dagger$ & & & & \\
\hline 1 & $1 / 1 / 1977$ & 451 & 1977-79 & 134 & $B+M$ & $\mathrm{TDI}+\mathrm{MDI}$ & $J+D$ & 727 \\
\hline 2 & $1 / 1 / 1975$ & 55 & 1975-79 & 67 & B & TDI & $J+D$ & 59 \\
\hline 3 & $1 / 1 / 1964$ & 995 & $1964-79$ & 2755 & $B+M$ & $\mathrm{TDI}+\mathrm{MDI}$ & $\mathrm{J}+\mathrm{D}$ & 1761 \\
\hline 4 & $1 / 1 / 1958$ & 323 & 1958-79 & 661 & B & TDI & $J+D$ & 531 \\
\hline 5 & $1 / 1 / 1970$ & 405 & 1970-79 & 698 & $M$ & TDI & $J+D$ & 339 \\
\hline 6 & $1 / 1 / 1968$ & 101 & $1968-79$ & 399 & $B+M$ & $\mathrm{TDI}+\mathrm{MDI}$ & $\mathrm{J}+\mathrm{D}$ & 205 \\
\hline 7 & $1 / 1 / 1972$ & 78 & 1972-79 & 78 & B & TDI+MDI & $J+D$ & 47 \\
\hline 8 & $1 / 1 / 1976$ & 252 & 1976-79 & 142 & $M$ & $\mathrm{TDI}+\mathrm{MDI}$ & $J+D$ & 240 \\
\hline 9 & $1 / 1 / 1972$ & 138 & $1972-79$ & 170 & $B+M$ & $\mathrm{TDI}+\mathrm{MDI}$ & $\mathrm{J}+\mathrm{D}$ & 355 \\
\hline 10 & $1 / 1 / 1976$ & 46 & 1976-79 & 93 & $B+M$ & $\mathrm{TDI}+\mathrm{MDI}$ & $\mathrm{J}+\mathrm{D}$ & 104 \\
\hline 11 & $1 / 1 / 1972$ & 86 & 1972-79 & 161 & $B+M$ & TDI & $J+D$ & 284 \\
\hline Total & - & 2930 & - & 5358 & - & & - & 4652 \\
\hline
\end{tabular}

* Number of employees in employment on the census date and first employed on an earlier date.

$\dagger$ Number of employees first employed in specified years of hire.

$\ddagger B$, block plant production; $M$, moulding.

$\S J$, job titles available; $D$, department titles available.

INumber of unique factory/job/department titles.

carcinogenic to humans). ${ }^{5}$ It is likely that IARC will wish to re-evaluate the carcinogenicity of TDI in humans at some time in the future, and updated information from the three available cohorts will assist such an evaluation. Ten years of additional follow up mortality data have been assembled for the UK cohort and updated findings are provided in this report. There has been little change in the quantities of diisocyanates used by the UK flexible foam industry in this period.

\begin{tabular}{|c|c|c|c|c|}
\hline \multirow[b]{2}{*}{ Variable with levels } & \multicolumn{3}{|l|}{ Deaths } & \multirow[b]{2}{*}{$\begin{array}{l}\text { Person-years- } \\
\text { at-risk }\end{array}$} \\
\hline & Lung cancer* & $\begin{array}{l}\text { Non-malignant } \\
\text { respiratory disease } \dagger\end{array}$ & All causes & \\
\hline \multicolumn{5}{|c|}{ Cumulative duration of "higher" exposure to diisocyanates (y) } \\
\hline None & 163 & 169 & 1610 & 191484.0 \\
\hline $0.01-4.99$ & 6 & 4 & 33 & 6126.6 \\
\hline$\geqslant 5.00$ & 0 & 2 & 19 & 2651.1 \\
\hline \multicolumn{5}{|c|}{ Cumulative duration of "lower" exposure to diisocyanates (y) } \\
\hline None & 136 & 152 & 1379 & 164660.0 \\
\hline $0.01-4.99$ & 14 & 10 & 125 & 21949.7 \\
\hline$\geqslant 5.00$ & 19 & 13 & 158 & 13652.6 \\
\hline \multicolumn{5}{|l|}{ Age } \\
\hline $15-19$ & 0 & 0 & 2 & 2531.6 \\
\hline $20-24$ & 0 & 0 & 4 & 10126.8 \\
\hline $25-29$ & 0 & 0 & 9 & 17181.3 \\
\hline $30-34$ & 0 & 0 & 22 & 22420.2 \\
\hline $35-39$ & 2 & 0 & 33 & 26049.6 \\
\hline $40-44$ & 4 & 0 & 50 & 26443.7 \\
\hline $45-49$ & 11 & 1 & 100 & 24691.2 \\
\hline $50-54$ & 15 & 5 & 131 & 21466.9 \\
\hline $55-59$ & 22 & 17 & 206 & 17656.7 \\
\hline $60-64$ & 34 & 23 & 253 & 13445.5 \\
\hline $65-69$ & 28 & 27 & 284 & 9225.4 \\
\hline 70-74 & 29 & 42 & 282 & 5477.6 \\
\hline 75-79 & 23 & 29 & 187 & 2582.4 \\
\hline $80-84$ & 1 & 31 & 99 & 963.1 \\
\hline \multicolumn{5}{|l|}{ Calendar period } \\
\hline $1958-70$ & 20 & 5 & 51 & 18952.2 \\
\hline $1971-80$ & 52 & 36 & 329 & 57188.0 \\
\hline $1981-90$ & 56 & 57 & 614 & 73194.6 \\
\hline $1991-98$ & 41 & 77 & 668 & 50927.1 \\
\hline \multicolumn{5}{|l|}{ Type of cohort } \\
\hline Entry cohort & 76 & 64 & 746 & 125883.0 \\
\hline Census cohort & 93 & 111 & 916 & 74379.2 \\
\hline \multicolumn{5}{|c|}{ Period from commencing employment (y) } \\
\hline $0-9$ & 20 & 12 & 161 & 64455.7 \\
\hline $10-19$ & 52 & 44 & 499 & 72452.2 \\
\hline $20-29$ & 56 & 70 & 601 & 46408.1 \\
\hline$\geqslant 30$ & 41 & 49 & 401 & 16946.0 \\
\hline \multicolumn{5}{|l|}{ Sex } \\
\hline Male & 134 & 140 & 1298 & 138561.0 \\
\hline Female & 35 & 35 & 364 & 61701.2 \\
\hline Total & 169 & 175 & 1662 & 200262.2 \\
\hline
\end{tabular}


Table 3 Mortality in UK polyurethane foam workers (5824 men, 2464 women), 1958-98

\begin{tabular}{|c|c|c|c|c|c|c|c|}
\hline \multirow[b]{2}{*}{ Cause of death } & \multirow[b]{2}{*}{ ICD-9 } & \multicolumn{3}{|c|}{ Males } & \multicolumn{3}{|c|}{ Females } \\
\hline & & Obs & Exp & SMR $(95 \% \mathrm{CI})$ & Obs & Exp & SMR (95\% CI) \\
\hline \multicolumn{8}{|l|}{ Cancers } \\
\hline Lip & 140 & 0 & 0.1 & $0(0$ to 3630$)$ & 0 & 0.0 & $0(0$ to 49214$)$ \\
\hline Tongue & 141 & 0 & 1.3 & 0 (0 to 279) & 0 & 0.3 & $0(0$ to 1491$)$ \\
\hline Salivary gland & 142 & 0 & 0.5 & 0 (0 to 718$)$ & 0 & 0.1 & 0 (0 to 3062$)$ \\
\hline Mouth & $143-145$ & 2 & 1.3 & 151 (18 to 544$)$ & 0 & 0.2 & 0 (0 to 1623$)$ \\
\hline Pharynx & $146-149$ & 6 & 2.7 & 227 (83 to 493 ) & 2 & 0.5 & 367 (44 to 1326 ) \\
\hline Oesophagus & 150 & 18 & 14.7 & 122 (72 to 193) & 3 & 2.8 & 107 (22 to 314$)$ \\
\hline Stomach & 151 & 23 & 27.3 & 84 (53 to 126$)$ & 6 & 5.0 & 120 (44 to 262$)$ \\
\hline Small intestine & 152 & 2 & 0.7 & 285 (35 to 1029) & 0 & 0.2 & 0 (0 to 1738$)$ \\
\hline Large intestine & 153 & 30 & 23.6 & 127 (86 to 182 ) & 7 & 8.9 & 78 (32 to 162$)$ \\
\hline Rectum & 154 & 10 & 15.3 & 65 (31 to 120) & 2 & 3.8 & 53 (6 to 192) \\
\hline Liver & $155.0,155.1$ & 3 & 3.4 & 88 (18 to 256$)$ & 0 & 0.8 & 0 (0 to 482$)$ \\
\hline Gallbladder & 156 & 0 & 1.6 & 0 (0 to 232$)$ & 0 & 0.8 & $0(0$ to 446$)$ \\
\hline Pancreas & 157 & 20 & 15.1 & 132 (81 to 204 ) & 9 & 4.6 & 194 (89 to 368 ) \\
\hline Peritoneum & 158 & 1 & 0.7 & 144 (4 to 801 ) & 1 & 0.2 & 469 (12 to 2611$)$ \\
\hline Other digestive & 159 & 3 & 1.8 & 169 (35 to 493) & 0 & 0.6 & $0(0$ to 656$)$ \\
\hline Nose and sinuses & 160 & 0 & 0.6 & 0 (0 to 598$)$ & 0 & 0.2 & 0 (0 to 2432$)$ \\
\hline Larynx & 161 & 4 & 3.5 & 116 (32 to 297) & 1 & 0.3 & 291 (7 to 1624) \\
\hline Lung and bronchus & 162 & 134 & 125.0 & 107 (90 to 127$)$ & 35 & 19.4 & 181 ** (126 to 251$)$ \\
\hline Pleura & 163 & 0 & 2.1 & $0(0$ to 175$)$ & 0 & 0.2 & 0 (0 to 2341$)$ \\
\hline Bone & 170 & 1 & 0.9 & 117 (3 to 651) & 0 & 0.2 & $0(0$ to 1681$)$ \\
\hline Connective tissue & 171 & 3 & 1.5 & 202 (42 to 589 ) & 2 & 0.5 & 376 (46 to 1358 ) \\
\hline Melanoma & 172 & 2 & 3.4 & 59 (7 to 215$)$ & 0 & 1.4 & 0 (0 to 262$)$ \\
\hline Skin, other & 173 & 2 & 1.0 & 205 (25 to 742 ) & 0 & 0.2 & $0(0$ to 1800$)$ \\
\hline Breast & 175 & 2 & 0.4 & 466 (56 to 1684 ) & 27 & 29.6 & 91 (60 to 133) \\
\hline Cervix & 180 & - & - & - & 7 & 5.1 & 137 (55 to 283 ) \\
\hline Uterus & 182 & - & - & - & 0 & 1.9 & 0 (0 to 197) \\
\hline Ovary & 183 & - & - & - & 8 & 9.3 & 86 (37 to 170$)$ \\
\hline Other genital & 184,187 & 0 & 0.5 & $0(0$ to 702$)$ & 1 & 0.6 & 159 (4 to 888$)$ \\
\hline Prostate & 185 & 26 & 22.9 & 114 (74 to 166$)$ & - & - & - \\
\hline Testis & 186 & 1 & 1.3 & 75 (2 to 417$)$ & - & - & - \\
\hline Bladder & 188 & 8 & 12.8 & 63 (27 to 123 ) & 2 & 1.8 & 109 (13 to 395$)$ \\
\hline Kidney & 189.0 & 8 & 7.6 & 106 (46 to 208 ) & 3 & 1.6 & 187 (39 to 547 ) \\
\hline Other urinary & $189.1-189.9$ & 0 & 0.4 & $0(0$ to 966$)$ & 0 & 0.1 & 0 (0 to 4158$)$ \\
\hline Eye & 190 & 0 & 0.4 & 0 (0 to 936) & 0 & 0.1 & $0(0$ to 2551$)$ \\
\hline Brain & $191-192$ & 7 & 10.5 & 67 (27 to 138) & 3 & 3.1 & 98 (20 to 287$)$ \\
\hline Thyroid & 193 & 1 & 0.6 & $173(4$ to 961$)$ & 0 & 0.4 & $0(0$ to 962$)$ \\
\hline Other endocrine glands & 194 & 1 & 0.3 & 305 (8 to 1701$)$ & 0 & 0.1 & 0 (0 to 2990$)$ \\
\hline Secondary and other cancers & $195-199$ & 25 & 23.0 & 109 (70 to 160$)$ & 13 & 7.9 & 164 (87 to 280 ) \\
\hline Hodgkin's disease & 201 & 1 & 2.3 & 44 (1 to 243 ) & 0 & 0.5 & $0(0$ to 702$)$ \\
\hline Non-Hodgkin's lymphoma & 200,202 & 6 & 9.2 & 65 (24 to 142$)$ & 3 & 2.7 & $110(23$ to 321$)$ \\
\hline Multiple myeloma & 203 & 7 & 4.7 & 148 (59 to 304$)$ & 0 & 1.5 & 0 (0 to 239$)$ \\
\hline Leukaemia & $204-208$ & 8 & 9.2 & 87 (37 to 171$)$ & 3 & 2.8 & 108 (22 to 317$)$ \\
\hline Lymphoid leukaemia & 204 & 1 & 2.7 & $37(1$ to 208$)$ & 0 & 0.6 & $0(0$ to 641$)$ \\
\hline Myeloid leukaemia & 205 & 3 & 5.6 & 54 (11 to 158$)$ & 2 & 1.9 & 106 (13 to 382 ) \\
\hline Monocytic leukaemia & 206 & 0 & 0.2 & $0(0$ to 1915$)$ & 1 & 0.1 & 1759 (45 to 9799) \\
\hline Other leukaemia & 207,208 & 4 & 0.8 & $507^{*}(138$ to 1298$)$ & 0 & 0.2 & $0(0$ to 1523$)$ \\
\hline All neoplasms & $140-239$ & 374 & 359.2 & $104(94$ to 115$)$ & 139 & 12.0 & 113 (95 to 133$)$ \\
\hline \multicolumn{8}{|l|}{ Non-cancers } \\
\hline Infectious and parasitic diseases & $1-139$ & 10 & 7.6 & 132 (63 to 243$)$ & 0 & 1.9 & $0(0$ to 191$)$ \\
\hline Endocrine nutritional and metabolic diseases & $240-279$ & 19 & 15.5 & 122 (74 to 191$)$ & 9 & 5.7 & 157 (72 to 298$)$ \\
\hline Diseases of blood & $280-289$ & 3 & 3.0 & 100 (21 to 293$)$ & 2 & 1.1 & $176(21$ to 636$)$ \\
\hline Mental disorders & 290-319 & 4 & 7.6 & 53 (14 to 135$)$ & 3 & 3.1 & 98 (20 to 286$)$ \\
\hline Diseases of nervous system & $320-389$ & 15 & 18.7 & 80 (45 to 133$)$ & 3 & 6.7 & 45 ((9 to 131$)$ \\
\hline Diseases of circulatory system & $390-459$ & 612 & 568.1 & 108 (99 to 117$)$ & 137 & 125.9 & 109 (91 to 129) \\
\hline Diseases of respiratory system & $460-519$ & 140 & 116.9 & $120 *(101$ to 141$)$ & 35 & 28.4 & $123(86$ to 171$)$ \\
\hline Diseases of digestive system & $520-579$ & 34 & 35.0 & 97 (67 to 136$)$ & 19 & 11.7 & 162 (97 to 253$)$ \\
\hline Diseases of genitourinary system & $580-629$ & 7 & 10.8 & $65(26$ to 133$)$ & 4 & 3.8 & 106 (29 to 271$)$ \\
\hline Diseases of skin & $680-709$ & 0 & 0.6 & $0(0$ to 588$)$ & 0 & 0.4 & $0(0$ to 938$)$ \\
\hline Diseases of musculo skeletal system & $710-739$ & 7 & 3.5 & 203 (82 to 418 ) & 4 & 2.9 & 139 (38 to 356$)$ \\
\hline Accidents & $800-949$ & 32 & 38.6 & $83(57$ to 117$)$ & 8 & 7.0 & 115 (50 to 227$)$ \\
\hline Suicide & $950-959$ & 25 & 20.1 & 124 (81 to 184$)$ & 1 & 3.9 & 26 (1 to 143 ) \\
\hline All causes & & 1298 & 1218.2 & $107 *(101$ to 113$)$ & 364 & 329.7 & 110 (99 to 122$)$ \\
\hline
\end{tabular}

Current annual use is estimated to be about 20000 tonnes of TDI and 1000 tonnes of MDI.

\section{METHODS}

\section{Subjects}

The cohort, the procedures for data collection and the use of isocyanates in the UK flexible polyurethane foam industry have been described previously'; the cohort comprises 8288 male and female production employees from 11 participating factories in England and Wales. The definition of the cohort is complex although all study subjects had some employment in the period 1958-79 and were employed for a minimum period of six months. The cohort is a mixture of entry cohorts $(\mathrm{n}=5321)$ and census cohorts (survivor populations) 
Table 4 Mortality in UK polyurethane foam workers (5824 men, 2464 women) by time since first employment, 1958-98

\begin{tabular}{|c|c|c|c|c|c|c|c|c|}
\hline \multirow[b]{2}{*}{$\begin{array}{l}\text { Time since first } \\
\text { employment (years) }\end{array}$} & \multicolumn{4}{|c|}{ Males } & \multicolumn{4}{|c|}{ Females } \\
\hline & Obs & Exp & $\operatorname{SMR}(95 \% \mathrm{Cl})$ & $\begin{array}{l}p \text { value for } \\
\text { trendt } t\end{array}$ & Obs & Exp & $\operatorname{SMR}(95 \% \mathrm{Cl})$ & $\begin{array}{l}\text { p value for } \\
\text { trendt }\end{array}$ \\
\hline \multicolumn{9}{|l|}{ All causes } \\
\hline $0-9$ & 125 & 162.3 & $77\left(^{* *}\right)(64$ to 92$)$ & & 36 & 42.1 & $86(60$ to 118$)$ & \\
\hline $10-19$ & 391 & 339.9 & $115^{* *}(104$ to 127$)$ & & 108 & 93.6 & 115 (95 to 139$)$ & \\
\hline 20-29 & 450 & 389.5 & $116 * *(105$ to 127$)$ & 0.16 & 151 & 124.6 & 121 * (103 to 142$)$ & 0.63 \\
\hline$\geqslant 30$ & 332 & 326.6 & $102(91$ to 113$)$ & & 69 & 69.4 & 99 (77 to 126) & \\
\hline Total & 1298 & 1218.2 & $107^{*}(101$ to 113$)$ & & 364 & 329.7 & 110 (99 to 122$)$ & \\
\hline \multicolumn{9}{|l|}{ Lung cancer $\ddagger$} \\
\hline $0-9$ & 16 & 15.3 & 105 (60 to 170 ) & & 4 & 1.9 & 215 (59 to 550$)$ & \\
\hline $10-19$ & 41 & 35.0 & 117 (84 to 159) & & 11 & 5.5 & 201 * (100 to 359$)$ & \\
\hline $20-29$ & 44 & 40.9 & 107 (78 to 144$)$ & 0.60 & 12 & 7.9 & 152 (79 to 266$)$ & 0.76 \\
\hline$\geqslant 30$ & 33 & 33.8 & 98 (67 to 137) & & 8 & 4.1 & 193 (83 to 380 ) & \\
\hline Total & 134 & 125.0 & 107 (90 to 127$)$ & & 35 & 19.4 & $181 * *(126$ to 251$)$ & \\
\hline \multicolumn{9}{|c|}{ Non-malignant diseases of the respiratory system } \\
\hline $0-9$ & 11 & 14.1 & 78 (39 to 139 ) & & 1 & 3.2 & 32 (1 to 177$)$ & \\
\hline $10-19$ & 38 & 30.3 & 125 (89 to 172$)$ & & 6 & 7.1 & $84(31$ to 183$)$ & \\
\hline $20-29$ & 55 & 36.7 & $150 * *(113$ to 195$)$ & 0.79 & 15 & 10.9 & 137 (77 to 227$)$ & 0.02 \\
\hline$\geqslant 30$ & 36 & 35.9 & $100(70$ to 139$)$ & & 13 & 7.2 & 180 (96 to 308$)$ & \\
\hline Total & 140 & 116.9 & $120 *(101$ to 141$)$ & & 35 & 28.4 & 123 (86 to 171$)$ & \\
\hline
\end{tabular}

${ }^{*} p<0.05,{ }^{*} p<0.01,(1)$ indicates deficit.

thinear component of trend over four time periods.

†ICD-9 162.

§ICD-9 460-519.

( $\mathrm{n}=2967$ ); the latter comprising those workers in employment on the earliest dates for which complete personnel records were still available. There were different dates for different factories; table 1 summarises the factory subcohorts.

The Office for National Statistics (ONS) has continued to supply the principal investigator with copies of death certificates (underlying cause coded to the 9th revision of the International Classification of Diseases (ICD-9)), cancer registration particulars (for the more limited period 1971-94), and emigration details relevant to study subjects. On the closing date of the survey (31 December 1998), there were 1704 $(20.6 \%)$ decedents, $163(2.0 \%)$ workers had emigrated, and $146(1.8 \%)$ workers were untraced. The mean period of follow up (date of hire to the end of the study period) was 26.3 years.

A total of 1436 study subjects were still employed at the end of 1986, of which 241 employees had been employed at two factories now closed. Work histories were left unchanged for these 241 employees. Company personnel departments provided updated work histories for the period 1987-97 for the remaining 1195 employees. The additional work histories were all coded in terms of the job dictionary containing 4612 unique factory/department/job entries used in the earlier analysis. ${ }^{1}$ Guided by the occupational hygiene data (1978-86) collected for the Medical Research Council isocyanate study ${ }^{6}$ each of these entries had been classified under one of four headings. A total of 189 entries had been classified by an occupational hygienist as "higher" exposure jobs (eight hour time weighted average exposure (TWA) for TDI was greater than $4 \mathrm{ppb}$ or excursions above $10 \mathrm{ppb}$ occurred on most days), 701 entries had been classified as "lower" exposure jobs (eight hour TWA for TDI was 1.5-4 ppb or occasional excursions above 5 ppb occurred), 94 entries were unclassifiable, and the remaining 3628 entries were classified as jobs involving minimal/zero exposure. "Higher" exposure jobs included block plant operative, polyester moulding process worker, and curing chargehand; "lower" exposure jobs included block stores controller and maintenance fitter; minimal/zero exposure jobs included sewing machinists, pillow fillers, stock clerks, and latex workers. The current ACGIH eight hour TLV for TDI exposure is $5 \mathrm{ppb}$; the short term exposure level (STEL) is $20 \mathrm{ppb}$.

\section{External standard (SMR)}

Expected numbers of deaths were calculated by applying sex, age, and period specific mortality rates for England and Wales to corresponding person-years-at-risk (pyr). Each study subject contributed pyr from the end of the six months minimum period of employment or the factory census date (see table 1), whichever was later, to the closing date of the study, death, emigration, or date last known alive, whichever was the earliest. SMRs were calculated as the ratio of observed deaths to expected deaths, expressed as a percentage. These procedures were carried out using the PERSONYEARS programme. ${ }^{7}$ Data were censored at age 85 years for three reasons. Firstly, published mortality rates are only available for the "open ended" age group $\geqslant 85$ years and the distribution of the cohort pyr by single years of age might be very different from that of the general population; secondly, the reliability of cause of death particulars is probably poorer at later ages; and thirdly, any study subjects incorrectly classified as traced alive at the end of the study would have a disproportionate effect on the expected numbers for the open ended age group. There were a total of 200262 pyr available for the updated analysis (1951-88: males 93983 pyr, females 41679 pyr; 1989-98: males 44578 pyr, females 20022 pyr). All tests of statistical significance were two tailed.

\section{Internal standard}

A number of variables were considered to have the potential for influencing mortality within the cohort: sex, attained age, calendar period, type of cohort (entry cohort/census cohort), period from commencing employment, cumulative duration of "higher" exposure to diisocyanates and cumulative duration of "lower" exposure to diisocyanates. Each variable was categorised into a number of levels (see table 2 ). The final models were constructed such that there was at least one death observed at each level of each variable. Any adjustments were made before statistical modelling was carried out.

The EPICURE computer program was used to provide both pyr and numbers of deaths for all combinations of all levels of the selected variables, ${ }^{8}$ and to carry out statistical modelling by means of Poisson regression, ${ }^{9}$ calculating point estimates of rate ratios (relative risks) for categories of work history variables with and without adjustment for other variables. 
Table 5 Mortality in male UK polyurethane foam workers with any period of "lower" or "higher" exposure to diisocyanates $(n=1782), 1958-98$

\begin{tabular}{|c|c|c|c|c|}
\hline Cause of death & ICD-9 & Obs & Exp & SMR $(95 \% \mathrm{CI})$ \\
\hline \multicolumn{5}{|l|}{ Cancers } \\
\hline Lip & 140 & 0 & 0.0 & 0 \\
\hline Tongue & 141 & 0 & 0.4 & 0 \\
\hline Salivary gland & 142 & 0 & 0.1 & 0 \\
\hline Mouth & $143-145$ & 1 & 0.4 & 276 (7 to 1537$)$ \\
\hline Pharynx & $146-149$ & 1 & 0.7 & 139 (4 to 773$)$ \\
\hline Oesophagus & 150 & 4 & 3.9 & 102 (28 to 262$)$ \\
\hline Stomach & 151 & 4 & 6.6 & 61 (17 to 155) \\
\hline Small intestine & 152 & 1 & 0.2 & 531 (13 to 2960 ) \\
\hline Large intestine & 153 & 10 & 6.0 & 166 (80 to 306$)$ \\
\hline Rectum & 154 & 6 & 3.9 & 155 (57 to 337$)$ \\
\hline Liver & $155.0,155.1$ & 0 & 0.9 & 0 \\
\hline Gallbladder & 156 & 0 & 0.4 & 0 \\
\hline Pancreas & 157 & 6 & 3.9 & 156 (57 to 338 ) \\
\hline Peritoneum & 158 & 0 & 0.2 & 0 \\
\hline Other digestive & 159 & 0 & 0.5 & 0 \\
\hline Nose and sinuses & 160 & 0 & 0.2 & 0 \\
\hline Larynx & 161 & 2 & 0.9 & 223 (27 to 806 ) \\
\hline Lung and bronchus & 162 & 36 & 30.8 & 117 (82 to 162 ) \\
\hline Pleura & 163 & 0 & 0.6 & 0 \\
\hline Bone & 170 & 1 & 0.2 & 435 (11 to 2421$)$ \\
\hline Connective tissue & 171 & 2 & 0.4 & 471 (57 to 1703 ) \\
\hline Melanoma & 172 & 0 & 1.0 & 0 \\
\hline Skin, other & 173 & 1 & 0.2 & 410 (10 to 2286$)$ \\
\hline Breast & 175 & 0 & 0.1 & 0 \\
\hline Prostate & 185 & 6 & 5.3 & 113 (42 to 247 ) \\
\hline Testis & 186 & 0 & 0.4 & 0 \\
\hline Other genital & 187 & 0 & 0.1 & 0 \\
\hline Bladder & 188 & 4 & 3.1 & 130 (36 to 334$)$ \\
\hline Kidney & 189.0 & 0 & 2.1 & 0 \\
\hline Other urinary & $189.1-189.9$ & 0 & 0.1 & 0 \\
\hline Eye & 190 & 0 & 0.1 & 0 \\
\hline Brain & $191-192$ & 2 & 3.0 & 66 (8 to 240$)$ \\
\hline Thyroid & 193 & 1 & 0.2 & 664 (17 to 3700$)$ \\
\hline Other endocrine glands & 194 & 0 & 0.1 & 0 \\
\hline Secondary and other cancers & $195-199$ & 7 & 6.0 & 117 (47 to 240$)$ \\
\hline Hodgkin's disease & 201 & 0 & 0.7 & 0 \\
\hline Non-Hodgkin's lymphoma & 200,202 & 3 & 2.5 & 118 (24 to 345$)$ \\
\hline Multiple myeloma & 203 & 3 & 1.2 & 245 (50 to 715$)$ \\
\hline Leukaemia & $204-208$ & 3 & 2.5 & $122(25$ to 357$)$ \\
\hline All neoplasms & $140-239$ & 107 & 91.1 & 117 (96 to 142$)$ \\
\hline \multicolumn{5}{|l|}{ Non-cancers } \\
\hline Infectious and parasitic diseases & $1-139$ & 2 & 2.0 & 99 (12 to 357$)$ \\
\hline Endocrine nutritional and metabolic diseases & $240-279$ & 4 & 4.1 & 99 (27 to 252$)$ \\
\hline Diseases of blood & $280-289$ & 1 & 0.7 & $136(3$ to 755$)$ \\
\hline Mental disorders & $290-319$ & 0 & 1.9 & 0 \\
\hline Diseases of nervous system & $320-389$ & 2 & 4.9 & $41(5$ to 148$)$ \\
\hline Diseases of circulatory system & $390-459$ & 150 & 138.8 & $108(91$ to 127$)$ \\
\hline Diseases of respiratory system & $460-519$ & 28 & 26.4 & $106(71$ to 153$)$ \\
\hline Diseases of digestive system & $520-579$ & 6 & 9.1 & 66 (24 to 143$)$ \\
\hline Diseases of genitourinary system & $580-629$ & 2 & 2.5 & $82(10$ to 295$)$ \\
\hline Diseases of skin & $680-709$ & 0 & 0.2 & 0 \\
\hline Diseases of musculo skeletal system & $710-739$ & 1 & 0.8 & 119 (3 to 665$)$ \\
\hline Accidents & $800-949$ & 8 & 11.3 & 71 (31 to 140 ) \\
\hline Suicide & $950-959$ & 6 & 6.1 & 98 (36 to 214$)$ \\
\hline All causes & & 319 & 303.7 & 105 (94 to 117) \\
\hline
\end{tabular}

More importantly, the statistical significance of any tendency for risks to increase or decrease progressively across levels of cumulative duration of exposed employment was assessed by means of linearly weighted p values for trend; the three levels for each of the two work history variables (see table 2) were scored $1-3$.

\section{RESULTS}

\section{External standard}

Table 3 shows observed and expected numbers of deaths both for individual sites of cancer and for broad categories of noncancer deaths for male and female employees. In males, there were significantly increased SMRs for all causes (Obs 1298,
SMR 107, p < 0.05), other and unspecified leukaemias (Obs 4, SMR 507, $<<0.05)$, and non-malignant diseases of the respiratory system (Obs 140, SMR 120, p < 0.05). Findings for all leukaemias were unexceptional (Obs 8, SMR 87) as were those for lung cancer (Obs 134, SMR 107). In females, a significantly increased SMR was shown only for lung cancer (Obs 35, SMR $181, \mathrm{p}<0.01)$. Findings for female cancer of the pancreas in the new period of follow up (1989-98) were unexceptional (Obs 3, SMR 125) whereas a further excess was shown for female lung cancer (Obs 19, SMR 184, p < 0.05).

Table 4 shows, for male and female employees, observed and expected numbers of deaths for all causes, lung cancer, and non-malignant diseases of the respiratory system by 
Table 6 Cancer registrations in UK polyurethane foam workers (5511 men, 2315 women), 1971-94

\begin{tabular}{|c|c|c|c|c|c|c|c|}
\hline \multirow[b]{2}{*}{ Site of cancer } & \multirow[b]{2}{*}{ ICD-9 } & \multicolumn{3}{|c|}{ Males } & \multicolumn{3}{|c|}{ Females } \\
\hline & & Obs & Exp & $\operatorname{SRR}(95 \% \mathrm{CI})$ & Obs & Exp & SRR $(95 \% \mathrm{CI})$ \\
\hline Lip & 140 & 1 & 0.95 & 105 (3 to 586$)$ & 0 & 0.07 & 0 \\
\hline Tongue & 141 & 0 & 1.88 & 0 & 0 & 0.40 & 0 \\
\hline Salivary gland & 142 & 0 & 0.94 & 0 & 0 & 0.34 & 0 \\
\hline Mouth & $143-145$ & 6 & 2.42 & 248 (91 to 540 ) & 0 & 0.46 & 0 \\
\hline Pharynx & $146-149$ & 3 & 3.29 & 91 (19 to 266) & 1 & 0.68 & 147 (4 to 819$)$ \\
\hline Oesophagus & 150 & 10 & 10.56 & 95 (45 to 174$)$ & 2 & 2.22 & 90 (1 1 to 325$)$ \\
\hline Stomach & 151 & 20 & 25.38 & 79 (48 to 122$)$ & 6 & 4.49 & 134 (49 to 291 ) \\
\hline Small intestine & 152 & 0 & 0.85 & 0 & 0 & 0.28 & 0 \\
\hline Large intestine & 153 & 27 & 26.84 & 101 (66 to 146 ) & 12 & 10.61 & 113 (58 to 198 ) \\
\hline Rectum & 154 & 17 & 21.90 & 78 (45 to 124$)$ & 5 & 5.68 & 88 (29 to 205$)$ \\
\hline Liver & $155.0,155.1$ & 4 & 2.65 & 151 (41 to 386 ) & 0 & 0.54 & 0 \\
\hline Gallbladder & 156 & 1 & 1.88 & 53 (1 to 296 ) & 1 & 0.87 & 115 (3 to 640) \\
\hline Pancreas & 157 & 10 & 11.45 & $87(42$ to 161$)$ & 7 & 3.43 & 204 (82 to 420$)$ \\
\hline Peritoneum & 158 & 1 & 0.64 & $156(4$ to 871$)$ & 0 & 0.24 & 0 \\
\hline Other digestive & 159 & 1 & 0.64 & 156 (4 to 871$)$ & 0 & 0.20 & 0 \\
\hline Nose and sinuses & 160 & 0 & 1.04 & 0 & 0 & 0.26 & 0 \\
\hline Larynx & 161 & 10 & 7.23 & 138 (66 to 254 ) & 3 & 0.60 & $500 *(103$ to 1461$)$ \\
\hline Lung and bronchus & 162 & 102 & 103.39 & 99 (80 to 120$)$ & 31 & 15.58 & $199 * * *(135$ to 282$)$ \\
\hline Pleura & 163 & 0 & 2.55 & 0 & 0 & 0.22 & 0 \\
\hline Bone & 170 & 0 & 0.90 & 0 & 0 & 0.26 & 0 \\
\hline Connective tissue & 171 & 4 & 2.32 & 172 (47 to 441$)$ & 2 & 0.81 & 247 (30 to 892 ) \\
\hline Melanoma & 172 & 3 & 5.89 & 51 (11 to 149) & 2 & 4.11 & 49 (6 to 176$)$ \\
\hline Skin, other & 173 & 45 & 57.67 & 78 (57 to 104$)$ & 11 & 17.71 & $62(31$ to 111$)$ \\
\hline Breast & 175 & 3 & 0.81 & 370 (76 to 1082$)$ & 51 & 52.86 & 96 (72 to 127$)$ \\
\hline Cervix & 180 & - & - & - & 10 & 9.97 & 100 (48 to 184$)$ \\
\hline Uterus & 182 & - & - & - & 2 & 6.83 & 29 (4 to 106$)$ \\
\hline Ovary & 183 & - & - & - & 8 & 9.67 & 83 (36 to 163 ) \\
\hline Other genital & 184,187 & 3 & 1.41 & 213 (44 to 622) & 1 & 1.31 & 76 (2 to 425$)$ \\
\hline Prostate & 185 & 30 & 30.71 & 98 (66 to 139$)$ & - & - & - \\
\hline Testis & 186 & 4 & 6.26 & 64 (17 to 164$)$ & - & - & - \\
\hline Bladder & 188 & 19 & 28.10 & $68(41$ to 106$)$ & 2 & 3.58 & 56 (7 to 202$)$ \\
\hline Kidney and other urinary & 189 & 8 & 9.87 & $81(35$ to 160$)$ & 4 & 2.04 & $196(53$ to 502$)$ \\
\hline Eye & 190 & 0 & 0.94 & 0 & 1 & 0.36 & 278 (7 to 1548$)$ \\
\hline Brain & $191-192$ & 7 & 9.17 & $76(31$ to 157$)$ & 1 & 2.70 & 37 (1 to 206 ) \\
\hline Thyroid & 193 & 1 & 1.12 & 89 (2 to 497$)$ & 1 & 1.19 & 84 (2 to 468$)$ \\
\hline Other endocrine glands & 194 & 2 & 0.51 & 392 (47 to 1417$)$ & 0 & 0.22 & 0 \\
\hline Secondary and other cancers & $195-199$ & 20 & 19.52 & 102 (63 to 158$)$ & 7 & 6.78 & 103 (42 to 213 ) \\
\hline Hodgkin's disease & 201 & 2 & 3.95 & 51 (6 to 183$)$ & 0 & 0.97 & 0 \\
\hline Non-Hodgkin's lymphoma & 200,202 & 6 & 12.15 & 49 (18 to 107$)$ & 4 & 3.75 & 107 (29 to 273$)$ \\
\hline Multiple myeloma & 203 & 9 & 4.78 & 188 (86 to 357$)$ & 0 & 1.49 & 0 \\
\hline Leukaemia & $204-208$ & 7 & 9.30 & 75 (30 to 155$)$ & 3 & 2.65 & 113 (23 to 331) \\
\hline All malignant neoplasms & $140-208 \dagger$ & 342 & 375.12 & 91 (82 to 101$)$ & 168 & 159.69 & 105 (90 to 122$)$ \\
\hline
\end{tabular}

successive 10 year periods from commencing employment. There was no indication that SMRs for lung cancer were increased more in later periods of follow up compared with earlier periods, in either group of employees ( $p$ value for trend: men, $\mathrm{p}=0.60$; women, $\mathrm{p}=0.76$ ). In females, however, there was a significant trend of SMRs for non-malignant diseases of the respiratory system increasing with period from hire $(p=0.02)$. There was no corresponding trend for males $(\mathrm{p}=0.79)$.

Table 5 shows observed and expected numbers of deaths both for individual sites of cancer and for broad categories of non-cancer deaths for those 1782 male employees with some period of "higher" or "lower" diisocyanate exposed employment. There were no significantly increased SMRs for any cause of death. An SMR of 117 was found both for lung cancer (Obs 36) and for all neoplasms (Obs 107). A similar analysis was carried out for the small exposed group $(n=90)$ of female workers (not shown in table). There were no deaths from cancers of the pancreas (Exp 0.11), lung (Exp 0.49), or kidney (Exp 0.04), or from non-malignant diseases of the respiratory system (Exp 0.60).

Table 6 shows observed and expected numbers of cancer registrations (1971-94) for male and female employees. Study subjects dying before 1971 or untraced at the ONS do not feature in these analyses. In males, there was no site of cancer for which registrations were significantly increased. In females, there were significantly increased standardised registration ratios (SRRs) for cancer of the larynx (Obs 3, SRR 500, $\mathrm{p}<0.05$ ) and for lung cancer (Obs 31, SRR 199, p < 0.001). In the new period of follow up (1987-94) there were no further cases in females of cancer of the larynx (Exp 0.30) or cancer of the kidney (Exp 1.14). An excess SRR persisted for female lung cancer (Obs 14, SRR 170).

\section{Internal standard}

Table 7 shows risks of mortality for lung cancer, nonmalignant diseases of the respiratory system, and all causes for two durations of "higher" exposure employment relative to risks in the never highly exposed category and corresponding analyses for duration of "lower" exposure employment. Durations of lower and higher exposure are separate time dependent variables and have been analysed simultaneously. The first column of relative risks were adjusted for sex, age, and calendar period. The second column of relative risks includes additional simultaneous adjustment for type of cohort (entry cohort/survivor population) and period from hire. None of the relative risks was significantly different from unity, and there were no significantly positive or negative trends of risks either with duration of lower exposure employment (all causes, $\mathrm{p}>0.50$; lung cancer, $\mathrm{p}=0.47$; non-malignant diseases of the respiratory system, $\mathrm{p}=0.32$ ) or with duration of higher exposure employment (all causes, $\mathrm{p}=0.20$; lung cancer, $\mathrm{p}>0.50$; 


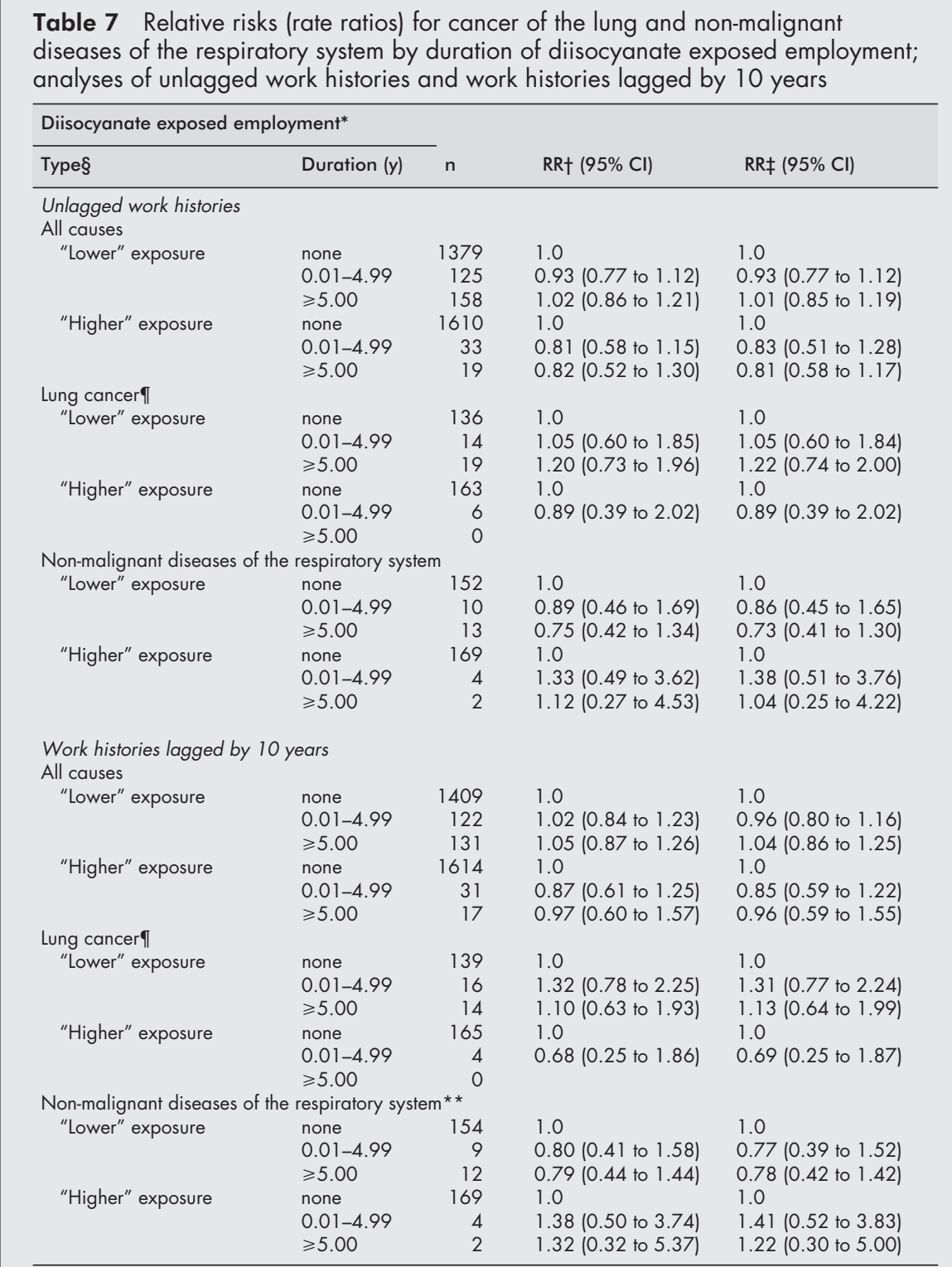

* Simultaneous analysis of two time dependent variables.

†Adjusted for age group, sex, and calendar period (see table 1 for levels).

$\ddagger$ Adjusted for age group, sex, calendar period, type of cohort, and period from hire (see table 1 for levels).

$\S$ See text for definition.

IICD-9 162.

**ICD-9 460-519.

non-malignant diseases of the respiratory system, $\mathrm{p}>0.50)$. None of the lung cancer cases had more than five years of higher exposure employment. The type of cohort had almost no influence on overall mortality; the rate ratio for all causes mortality in the census cohorts compared with the entry cohorts was 1.04 (95\% CI 0.93 to 1.17$)$.

Table 6 also shows the same analyses with employment histories "lagged" by 10 years-that is, periods of lower or higher exposure employment are not considered until a further 10 years have elapsed. None of the relative risks was significantly different from unity, and there were no significantly positive or negative trends of risks either with duration of lower exposure employment (all causes, $\mathrm{p}>0.50$; lung cancer, $\mathrm{p}>0.50$; nonmalignant diseases of the respiratory system, $\mathrm{p}=0.37$ ) or with duration of higher exposure employment (all causes, $\mathrm{p}>0.50$; lung cancer, $\mathrm{p}=0.46$; non-malignant diseases of the respiratory system, $\mathrm{p}>0.50$ ).

\section{DISCUSSION}

This study has found overall increased rates of lung cancer (for both mortality and morbidity) in female workers from the flexible polyurethane foam industry but unexceptional rates of lung cancer in male workers. Similar findings were shown in the first report, ${ }^{1}$ and it follows that the increased lung cancer rates in females are unlikely to be chance findings. There was no indication, however, that these increased rates were caused by exposure to isocyanates. All female lung cancer cases occurred in women without any period of isocyanate exposed employment, and there was no indication in the total study population (males and females) that lung cancer risks were associated with duration of isocyanate exposed employment. The possible role of nine other occupational exposures (amine catalysts, non-flammable solvents, flammable solvents, polyurethane dust, latex, rubber, curled hair/coir fibre, feathers, foam handling) in the pattern of lung cancer risks 
experienced by females in this cohort was investigated in the first report ${ }^{1}$; none of these exposures was implicated. Such other occupational exposures in the industry under study offer an unlikely explanation for the increased rates, given that female lung cancer SMRs were marginally higher in the first two 10 year periods following hire than they were in later periods of follow up. It might be expected that the opposite pattern would be shown if an occupational lung cancer hazard had been present. Unfortunately, it has not been possible to evaluate the role of smoking habits or dietary factor ${ }^{10}$ in these findings.

Some attention was given in the original report ${ }^{1}$ to findings in female workers for cancers of the pancreas, larynx, and kidney. There have been no further cases of cancers of the larynx or kidney in the new period of follow up for cancer incidence data (1989-94), and the overall SRRs for both cancer sites in female workers are no longer significantly increased. In a similar vein, the original increased rates for cancer of the pancreas (mortality and incidence) have not been maintained in the new period of follow up and the overall SMR and SRR for this site of cancer in female workers are no longer significantly increased.

In female workers there was a significant trend of SMRs for non-malignant diseases of the respiratory system increasing with decade from hire. Similar findings were not found for male workers and in the more sophisticated analyses, risks for this disease grouping were not found to be associated with duration of isocyanate exposed employment. Given the large number of statistical comparisons that have been carried out, some chance findings are to be expected, and the positive trend for female workers may well be such a finding. Only three deaths were recorded as being caused by asthma and none of these individuals had had any period of higher exposure employment.

The cohort definition is complex which is unattractive. Nevertheless, there was no evidence of the presence of census cohorts introducing major selection effects into the analysis. There are limitations to be attached to the use of the exposure surrogates used in these analyses. These surrogates take no account of any changes in intensity of job specific exposures over time. While exposure conditions in the 1980s and 1990s were similar, it may be the case that concentrations in earlier periods were higher. In addition, it needs to be recognised that this cohort study, along with the Swedish and US studies, relate to an industry that operates with well controlled exposure conditions, and that all the available human studies are "low" exposure studies. Nevertheless this study has been unable to link cancer risks or risks from non-malignant diseases of the respiratory system to occupational isocyanate exposure.

\section{ACKNOWLEDGEMENTS}

We thank the Office for National Statistics for continuing to provide follow up details for the study. We also thank Julian Bugler for the exposure assessments, Margaret Williams for word processing, and the management and workforce of the industry concerned for supporting the project.

Authors' affiliations

T Sorahan, L Nichols, Institute of Occupational Health, University of Birmingham, Edgbaston, Birmingham, UK

\section{REFERENCES}

1 Sorahan T, Pope D. Mortality and cancer morbidity of production workers in the United Kingdom flexible polyurethane foam industry. $\mathrm{Br} J$ Ind Med 1993:50.528-36.

2 Hagmar L, Welinder H, Mikoczy Z. Cancer incidence and mortality in the Swedish polyurethane foam manufacturing industry. Br J Ind Med 1993;50:537-43

3 Hagmar L, Stromberg $U$, Welinder $\mathrm{H}$, et al. Incidence of cancer and exposure to tolvene diisocyanate and methylene diphenyldiisocyanate: a cohort based case-referent study in the polyurethane foam manufacturing industry. Br J Ind Med 1993;50:1003-7.

4 Schnorr TM, Steenland K, Egeland GM, et al. Mortality of workers exposed to tolvene diisocyanate in the polyurethane foam industry. Occup Environ Med 1996;53:703-7.

5 International Agency for Research on Cancer. IARC monographs on the evaluation of the carcinogenic risk of chemicals to humans. Re-evaluation of some organic chemicals. Vol 71. Lyon: IARC, 1999

6 Clark RL, Bugler J, McDermott M, et al. An epidemiological study of lung function changes of tolvene diisocyanate foam workers in the United Kingdom. Int Arch Occup Environ Health 1998;71:169-79.

7 Coleman M, Douglas A, Hermon C, et al. Cohort study analysis with a Fortran computer program. Int J Epidemiol 1986;15:134-7.

8 EPICURE. Hirosoft International Corporation, Seattle, 1988.

9 Breslow NE, Day NE. Statistical methods in cancer research. Volume II-The design and analysis of cohort studies. IARC Scientific Publication no. 82. Lyon: IARC, 1987

10 Darby $S, W h i t l e y E$, Doll $R$, et al. Diet, smoking and lung cancer: a case-control study of 1000 cases and 1500 controls in south-west England. Br J Cancer 2001;84:728-35. 